\title{
Legal implementation of blockchain technology in pharmacy
}

\author{
Vitalii Pashkov ${ }^{1}$ and Oleksii Soloviov ${ }^{2}$ \\ ${ }^{1}$ Poltava Law Institute, Poltava, Ukraine \\ ${ }^{2}$ Shupyk National Medical Academy, Kiev, Ukraine
}

\begin{abstract}
Author analyzes the possibilities of using blockchain technology in pharmaceutical sphere with the purpose of detection of counterfeit and poor-quality medicinal products and discusses the legal acts concerning the use of this technology. Author examines the grounds for the legal provision of blockchain technology in pharmaceutical sector in order to protect the rights of patients. The necessity of legal regulation of the use of blockchain technology by private parties is substantiated taking into account the private legal nature of this system. The mechanism of application of this technology in pharmaceutical activity is revealed.
\end{abstract}

Key words: counterfeit medical products, fake medicine, blockchain technology.

\section{Introduction}

The study of legal aspects of preventing the spread of falsified medicines is highly relevant from both theoretical and practical point of view. Negative consequences, caused by the spread of falsified medicines are so obvious that there is a need for modern technologies for their detection. The use of blockchain technology in pharmacy could provide a reliable legal protection of the supply of pharmaceutical products and its tracking. Such system could provide significant simplification of audit and control of pharmaceutical products, including by the specially authorized bodies. Healthcare and the pharmacy industry specifically, could employ blockchain to streamline efficiencies, improve privacy and confidentiality, enhance patients' safety, and provide a higher level of clinical care to consumers. The main advantages of the blockchain technology are the maximum transparency, speed and accuracy of transactions. Although the investment in blockchain technology is relatively low, it is rapidly growing. For example, IBM and Microsoft are incorporating blockchain platforms in their customer support systems. Additionally, major companies are actively exploring the value of integrating blockchain technology into their operations. Examples are Walmart vendor payment and digital shopping; Starbucks - tracing beans from various countries; American Express - collaborating with Boxed to customize rewards for cardholders; JD.com - use blockchain technology to accelerate AI development.

\section{Aim}

The aim of this study is to explore the potential of blockchain technology in ensuring patients' rights to quality pharmaceuticals. 


\section{Material and methods}

This study examines provisions of international documents and scientists' attitudes. Author analyzes generalized information from scientific journals by means of scientific methods from medical and legal point of view. This article is based on dialectical, comparative, analytic, synthetic and comprehensive research methods.

In order to achieve this goal Directive 2011/62/EU of the European parliament and of the Consul of 8 June 2011 amending Directive 2001/83/EC on the Community code relating to medicinal products for human use, as regards the prevention of the entry into the legal supply chain of falsified medicinal products has been analyzed. The international aspects of pharmaceutical activity of the USA and certain European countries are investigated. During the study, methods of data extraction and content analysis were used along with scientific publications of leading specialists in the pharmaceutical law field.

The methodology of this scientific publication is based on the organic combination of philosophical approaches, and general scientific and special legal research methods. In particular, the systematic method is used to carry out a systematic analysis of European legislation on the circulation of medicines and the protection of patients' rights. The comparative method allows the author to compare the experience of foreign countries in the patients' rights legal protection area. The legal modelling method is used to formulate proposals for improvement of existing legislation and practice in the field of patients' rights protection.

The analysis of scientific sources clearly shows that the issues of pharmaceutical activity and patients' rights have been studied by recognized scholars, namely: A. Harkusha [1, 2], N. Gutorova [3], A. Olefir [4] and others. Meanwhile, the problems of legal provision of Blockchain technology use in pharmacy have not been studied sufficiently.

\section{Results}

The legal basis for the introduction of Blockchain in pharmacy is Directive 2011/62/EU of the European Parliament and of the Consul of 8 June 2011 amending Directive 2001/83 / EC on the Community code relating to medicinal products for human use in respect of the prevention of the entry of falsified medicinal products into the legal supply chain. This document, which came into force on January 2013, stipulates that the manufacturer can mark drugs registered in the country with the unique identifier.

The directive also provides for the introduction of a system that helps the consumer to identify legitimate websites that sell legal drugs through a recognizable logo. In the United States, Great Britain, Ukraine and most EU countries such rules are based on the legal act for quality and safety of medicines.

Substandard and falsified medical products, as defined by the World Health Organization, are major threats to public health. Through increasing globalisation, the problem has expanded in both developed and developing countries [5].

Sale of fake medicines is rising rapidly and is considered a global epidemic. It is estimated WHO that 10-30\% of drug market is counterfeit, with the upper end of that range predominantly in emerging regions [6]. For example, in 2015 as part of Interpol's Operation Giboia more than 150 tons of counterfeit and illicit medicines for nearly USD $3.5 \mathrm{~m}$ were seized in seven African countries.

With regards to internet sales over 20.7 million counterfeit and illicit medicines, including products for blood pressure medicines, erectile dysfunction and cancer as well as nutritional supplements, were seized by Interpol's Operation Pangea in 2015 [7]. 
The falsification and distribution of counterfeit medicines and other medical products is one of the most serious crimes against public health. As any other fraudulent economic activity, this crime is harmful to legal producers, distributors and pharmacy establishments that lose their income and sometimes also are compelled to compete with distributors of counterfeit goods.

But the worst consequences are the damage to people's life and health, which cannot be overestimated. The range of such damage vary from distrust of doctors, resulting from the ineffectiveness of treatment, to causing death or serious harm to health due to the use of poor quality medication and/or the lack of proper therapeutic effect, false diagnostic results, etc. These effects are not always easy to establish, it is even more difficult to prove the existence of a causal link between the use of counterfeit medicines and caused harm to human life or health [8]. However, existing global pharmaceutical supply chains are complex and work with outdated platforms that do not provide effective partnerships for regulatory compliance and cannot guarantee the security of drug distribution [9]. That is why researchers say that an automatic drug tracking system should be an effective component of preventing the spread of counterfeit medicines through the individual coding of each package, as is the case in EU countries [10].

Another effective reason for the introduction of blockchain technology is the Council of Europe Convention of 28.10.2011 on the counterfeiting of medical products and similar crimes involving threats to public health. In accordance with this international legal instrument, crimes in this area are deemed deliberate fabrication, supply or proposal of supplies, including mediation, trade, including storage in the warehouse, import and export of counterfeit medical products (medicines for human and veterinary use and medical devices), active substances, parts, materials and accessories (Articles 4, 5 and 6 of the Convention).

The implementation of the provisions of this Convention provides for the imposition of sentences of imprisonment for such crimes, strengthening of penalties for persons who have committed crimes in their professional or official duties (through the abuse of trust given to them as professionals or as producers or suppliers). An important aspect of Convention is the provision of the possibility of bringing legal entities to justice for crimes established in accordance with this Convention committed in their favor by any natural person who acted in person or as a part of a legal entity and held a leading position within this legal entity.

Meanwhile, researchers say: "Digital technology has been one of the most significant drivers impacting our businesses and our lives. Blockchain has the potential to be very disruptive to our healthcare supply chain. It's important for healthcare stakeholders, including pharmacy, to really understand the potential implications and be strategically positioned to evaluate and potentially adopt the "fast-moving" commercial applications as blockchain integrates with mainstream healthcare supply chain" [11].

The US experience shows that there are risks of using the digital system - fraud and forgery. That is why the United States continues to look for the ways to protect personal data of patients when they issue prescription drugs due to the risk of their digitization [12]. Meanwhile, in May 2018, updated personal data processing rules established by the General Data Protection Regulation (EU Regulation 2016/679 of April 27, 2016 or GDPR - General Data Protection Regulation) entered into force in the EU. This regulation has direct effect in all 28 EU countries, will replace the Framework Directive on personal data protection 95/46/EC of October 24, 1995. An important nuance of GDPR is the extraterritorial principle of the new European rules for the processing of personal data. That is, GDPR applies to all companies that handle personal data of residents and EU citizens regardless of location of such company. 
Blockchain enables that data sharing capability without sacrificing privacy while offering pharmacists the ability to verify the source of the medicine. Blockchain could provide pharmacists with appropriate level of ensuring of patient safety by verifying the source of supplies of medicines.

In addition, the blockchain technology allows to create new decisions to control the circulation of drugs, in particular, in terms of compliance with the temperature regime in transferring of drugs [13].

Blockchain Technology is a public registry that is based on cryptographic system algorithms. It stores data about all operations and changes that have occurred in system, is decentralized and grounded on public Internet services.

The basic principles of the Blockchain system are: 1) decentralization; 2) the absence of intermediaries; 3) public availability (publicity); 4) the consensus of the participants [14].

It should be noted that supply chain management (SCM) has been used for a long time before [15]. Supply Chain Management (SCM) or Supply Chain Management is the term that came into circulation relatively recently. This concept is voluminous and includes the definitions used earlier, such as ECR (Efficient Customer Response) and DRP (Distribution Resource Planning).

Blockchain enables that data sharing capability without sacrificing privacy while offering pharmacists the ability to verify the source of the medicine [16]. In addition, for example in the United States the federal government more and more often puts the pharmaceutical industry in charge of controlling the supply chain for illicit and non-standard drug orders [17].

To date, the patient cannot track which drug is being sold to him, both at an independent procurement and in inpatient treatment. Although the patient has the right to demand for example a quality certificate for a medicinal product, nobody prevents an unscrupulous vendor or employee of a pharmacy institution from tampering with it.

However, if all the information is stored in the blockchain from the moment of clinical research, production, further storage and delivery to the pharmacy and/or its structural subdivision, including the medical institution, it will be possible to trace the entire chain.

It is clear that this system can be modified by adding of additional functionality, for example, the rules for drugs storage and treatment of inpatients. It is possible to establish to whom drugs were transferred and, in general, to what extent they are needed. For this purpose, the packaging of medicinal product (for instance) has a barcode using which one could via special application enter blockchain. And there is second important characteristic of Blockchain - it is irremovable. The information once stored in it cannot be modified or deleted, which is a huge advantage over the standard database in which data can easily be falsified also with hiding the fact of making any changes in it.

Thus, checking the reliability of information on the effectiveness of drugs, their effectiveness, safety, including adverse reactions may become available to the patient by dint of blockchain system [9].

Huge pharmaceutical conglomerates like Pfizer and Genentech with a total market capitalization of over $\$ 300$ billion announced the creation of a blockchain project MediLedger. It is based on the Ethereum-based Quorum platform, the purpose of creating a blockchain - to block access to the supply chain for counterfeit goods [18].

In addition, thanks to the new Ethereum system pharmaceutical manufacturers will be able to detect poor-quality medicines before they enter the supply chain [19].

A separate sphere of blockchain technology use is clinical research. Such aspects of blockchain as decentralized transaction verification, transparency of information are useful for clinical research. And that is why in January 2018 pharmaceutical companies Pfizer, 
Amgen and Sanofi announced the creation of a blockchain platform for clinical trials to reduce the cost of developing and testing of new drugs [20].

According to experts, the confidentiality and transparency problems in clinical trials of medicines may hinder future drug development and increase costs. In order to overcome the confidentiality issues, it was decided to turn to such a new technology as Blockchain [21].

When conducting clinical studies with the help of Blockchain technology it is monitored: 1) the place, time, period, performers of clinical trials; 2) the order of testing and the level of patient health at different stages of research of pharmaceutical products; 3) the results of the tests.

Disclosure of clinical trial data is rapidly becoming a top priority for both large and small pharmaceutical companies in the United States [22].

The Blockchain system will allow interested patients to make their personal data available to pharmaceutical companies and research institutions. At the same time, the research results will be automatically recorded in the blockchain with no possibility of making changes or falsifying research results. In general, the clinical trials' registration taking into account unclear legal status of the experiment participant is a relevant problem [14].

Blockchain technology allows you to observe the chain of supply: 1) all information is stored in Blockchain from the time of release and till entering to the retail network, then you can add functional to this system, for example, to control the drugs in medical institutions; 2 ) the conditions of storage of medicinal products during their delivery (temperature regime) are also monitored; 3 ) it is possible to trace to whom concrete drugs were given, in what amount (for that purpose there is a bar code on a medicine package).

Thus, Blockchain technology allows: 1) to improve the clinical trials of drugs; 2) to improve the procedure of licensing of pharmaceutical products; 3 ) to track the quantity of pharmaceutical products from the manufacturer with the further selling thereof; 4) to track sources of origin of pharmaceutical products and the procedure for their use; 5) to monitor the registration period, expiration date, conditions of transportation and storage of pharmaceutical products; 6) to limit the activities of online pharmacies that do not have permits; 7) to minimize the possible shortage of pharmaceutical products; 8) to ensure openness to all partners.

In addition, the use of Blockchain technology in pharmacy can provide reliable legal protection for the supply of pharmaceutical products, tracking it's transferring from manufacturer to patient. The system provides for simplification of audit and control of pharmaceutical products, including by the specially authorized bodies.

However, it must be noted that the existing legal framework for the use of Blockchain technology is imperfect, although de facto used in the field of pharmaceutical activity. The use of this technology not only minimizes the risks of supplying counterfeit medicines to patients but also provides for transparency of delivery and reduced costs for logistics. As a consequence, there is a reduction in prices of final product for patients. However, application of Blockchain technology requires appropriate legal support.

Analysis of the prospects for using Blockchain technology allows us to establish that the objects of legal relationships in this technology are: 1) computer software; 2) telecommunication networks; 3) informational resources, products and services; 4) patients' health rights; 5) informational security.

Meanwhile, Blockchain's relationship in healthcare has a private-law nature (dispositive), despite the publicity of using Blockchain. As a result, the lack of imperative principles for the use of Blockchain technology in pharmacy, including in terms of patient rights ensuring can undermine the ability to use such cutting-edge and advanced technologies. 
The technology of blockchain in pharmacy allows the use of so-called smart contracts between contractors. Smart contract is an electronic protocol written using a computer code. His appointment is the transfer of information and enforcement of contract terms by both parties.

Smart contracts provide security for the transaction and devoid of the risk of ambiguous interpretation of the conditions, due to the fact that they are based on cryptography. They are much more beneficial deals financially because a person does not need to pay lawyers, intermediaries etc. The terms of the agreement are implemented automatically with the minimum cost for their support, without the involvement of third parties (intermediaries) because smart contracts are based on blockchain technology.

This is a distributed registry, which is a decentralized system that exists due to the myriad of computers that are integrated into a single network. Blockchain allows users to execute transactions, transfer information and material value without banks and intermediaries. If information is stored in a blockchain, which everyone trusts, most of the process can be automated. As soon as the records enter the chain, the smart contract checks whether all conditions are fulfilled and exercise payment. If there's not enough information it asks for an additional study of the situation. The widest dissemination of smart contracts is observed in business sector in payments and payment-related actions [23].

\section{Conclusions}

One must admit that the existing legal basis for the use of blockchain technology is imperfect, although it is de facto used in the field of pharmaceutical activity. The use of blockchain technology not only minimizes the risks of supplying counterfeit medicines to patients, but also ensures transparency of delivery and reduction of logistics costs. Consequently, there is a reduction in price of the final product for patients. However, full engagement of blockchain technology in pharmacy requires adequate legal support.

\section{References}

[1] Vitalii Pashkov, Andrii Harkusha, Certain aspects on medical devices software law regulation. Wiadomości Lekarskie LXIX(6), 765-767 (2016)

[2] Vitalii Pashkov, Alla Kotvitska, Andrii Harkusha, Legal regulation of the production and trade of medical devices and medical equipment in the EU and USA: experience for Ukraine. Wiadomości Lekarskie LXX(3) cz. II., 614-618 (2017)

[3] Vitalii Pashkov, Nataliya Gutorova, Andrii Harkusha, Medical device software: defining key terms. Wiadomości Lekarskie LXIX(6), 813-817 (2016)

[4] Vitalii Pashkov, Andrii Olefir, The impact of the legal regime of intellectual property protection in the pharmaceutical market. Wiadomości Lekarskie LXIX(3) (cz. II), 582-587 (2016)

[5] International Pharmaceutical Federation (FIP), FIP is the global federation representing four million pharmacists and pharmaceutical scientists worldwide. URL: https: //www.fip.org/counterfeit_medicines

[6] WHO. Substandard and falsified medical products, URL: https://www . who.int/ news-room/fact-sheets/detail/substandard-and-falsified-medicalproducts

[7] International Pharmaceutical Federation (FIP), FIP is the global federation representing four million pharmacists and pharmaceutical scientists worldwide. URL: https://www.fip.org/counterfeit_medicines 
[8] Гуторова Н. Відповідальність за фальсифікацію лікарських засобів: чи створена в Украині належна правова база? Шотижневик АПТЕКА. 2018 № 2 (1173). C. 11. URL: https://www.apteka.ua/article/485029? fbclid=IwAR3TM8hbt0ou30daeR9FTRyNxNG4zO_4z4jhSLwvwMf jqZD5TL7Hcq_ jByQ

[9] Blockchain Tech Could Track Pharmacy Supply Chain. Drug Topics. Nov 9, 2017/ URL: http://www.drugtopics.com/latest/blockchain-tech-couldtrack-pharmacy-supply-chain

[10] Гуторова Н. Фальсифікація лікарських засобів - як в Україні суворість кримінально-правової норми поєднується 3 фактичною безкарністю фальсифікаторів? Шотижневик АПТЕКА. 2018. № 4 (1175). C. 8-9. URL: https://www.apteka.ua/article/486071?fbclid= IwAR2EXhpqPnhxFnaZ6ujzeh8VTsN_5mz4elXJbOIamwUOG5ahNDSIKFYh-hk

[11] David J. Fong. Blockchain and Its Potential Impact to Healthcare and Pharmacy. URL: https://www . wolterskluwercdi.com/blog/blockchain-potentialimpacts/

[12] How Blockchain Can Reduce Waste for Pharmaceutical Companies. Finance magnates. Tuesday, 16/01/2018. URL: https://www.financemagnates. com/thought-leadership/blockchain-can-reduce-waste-pharmaceuticalcompanies /

[13] ЕгороваН. ЕС вводит новые правила для фармацевтов, применяющих блокчейн. URL: https://getway.io/ru/eu-vvodit-novyye-pravila-dlyafarmatsevtov-primenyayushchikh-blokcheyn

[14] ПашковВ.М. Блокчейн Системі Охорони Здоров'я: проблеми правового забезпечення. Медичне Право 2018. №2(22). С. 32-40

[15] Supply Chain Management (SCM) или управление цепочкой поставок. Logistics.ru. URL: http://www.logistics.ru/21/7/1/i8_466.htm

[16] Blockchain Tech Could Track Pharmacy Supply Chain. Drug Topics. 2017. № 9. URL: http://www.drugtopics.com/latest/blockchain-tech-could-trackpharmacy-supply-chain

[17] Bill Siwicki. The next big thing in pharmacy supply chain: Blockchain. Healthcare IT News. 2017. № 12. URL: https://www.healthcareitnews. com/news/next-big-thing-pharmacy-supply-chain-blockchain

[18] Pfizer и Genentech создает блокчейн-проект MediLedger для борьбы с поддельными медицинскими товарами. Подробности. Опубликовано: 05 Октябрь 2017. Tutellus. URL: http://www.coinfox.ru/novosti/7780pfizer-i-genentech-sozdayut-blokchejn-proekt-mediledger-dlyaborby-s-poddelnymi-meditsinskimi-tovarami

[19] В России будут бороться с подделкой лекарств с помощью блокчейна. Forklog. 31.01.2017. URL: https://forklog.com/v-rossii-budut-borotsyas-poddelkoj-lekarstv-s-pomoshhyu-blokchejna/

[20] Полина Гиверц. Потенциал Применения Технологии Блокчейн В Фармации. DigitalMedInfo. URL: http://digitalmedinfo.ru/ blockchainpharm

[21] Как блокчейн может улучшить фармацевтическую промышленность. Coinspot. URL: https://coinspot.io/technology/kak-blokchejnmozhet-uluchshit-farmacevticheskuyu-promyshlennost/ 
[22] Mohamad Zahreddin, How Blockchain Will Revolutionize the Pharmaceutical Industry. Forbes Technology Council. 2018. №14. URL: https://www . forbes.com/sites/forbestechcouncil/2018/11/14/how-blockchain-willrevolutionize-the-pharmaceutical-industry/\#468c242726e5

[23] Что Такое Смарт-контракты простым языком. Prosto coin. URL: https://prostocoin.com/blog/smart-contract 